\title{
Intergenerational social mobility in urban Mexico
}

\author{
Fernando Cortés and Agustín Escobar Latapi
}

Fernando Cortés

Research Professor,

Sociological Studies Centre,

El Colegio de México

○ fcortes@colmex.mx

Agustín Escobar Latapí

Research Professor,

Centre for Research and Higher Learning

in Social Anthropology (CIESAS),

Guadalajara, Mexico

$\bullet$ ageslat@fastmail.fm

$\mathrm{T}$

his article assesses changes in absolute and relative opportunities of access to the upper strata of the urban social and occupational structure in Mexico, drawing on data from the largest retrospective social mobility survey carried out in the country, which covers all the largest cities and some medium-sized ones. It analyses intergenerational mobility in three periods: before 1982, from 1982 to 1988, and from 1988 to 1994 . The results show a striking decline in opportunities of access to the stratum of professionals, managers and executives and large employers. This decline has not been linear but has affected first and foremost those from the lowest strata, then those from privileged strata, while leaving the intermediate strata of the sociooccupational structure virtually unaffected. The article also analyses the evolution of absolute and relative opportunities by gender. 


\section{I}

\section{Introduction}

Since they originated in the early twentieth century, social mobility studies ${ }^{1}$ have been exploring the links between social mobility systems and economic systems. The nature of these links was examined in the pioneering social mobility studies in the United States (Sorokin, 1927), and then in the rest of the industrialized Western world (Lipset and Zetterberg, 1959). Since the 1970s, most works dealing with the subject have been based on the so-called "FJH hypothesis" (FJH standing for Featherman, Jones and Hauser),${ }^{2}$ which states that social mobility systems in Western industrial societies are fluid and homogeneous to a high degree.

The debate has given rise to a fundamental disagreement between liberal sociologists and materialists. The former argue that, particularly since market reform, the market-based industrial and postindustrial economic structure necessarily involves a fairly constant expansion of social mobility opportunities, i.e., an equalling out of opportunity (Featherman, Jones and Hauser, 1975). The latter hold a variety of positions, but are at one in arguing that no such tendency exists (Goldthorpe, 1987; Erikson and Goldthorpe, 1992; Haller, 1990). In these analyses, then, the idea of a close relationship between the economic system and the social mobility system is central.

These ideas can be explored in Latin America, which has moved from the domestic market-oriented accumulation model that was responsible for the region's urbanization, growth and development to a model that, broadly speaking, has resulted in a decline

$\square$ The material analysed here is taken from the project "Género, edad, familia y trabajo: la reestructuración de la sociedad urbana en México", directed by Agustín Escobar and financed by the Ford Foundation, the National Council for Science and Technology (СONACYT) and the Centre for Research and Higher Learning in Social Anthropology (CIESAS). M. González de la Rocha, R.M. Rubalcava and B. García provided generous and helpful comments on a number of preliminary versions.

${ }^{1}$ In this, as in most other studies on the subject, occupational mobility is equated with social mobility, owing to the close relationship between the two. Mexico is no exception. See below for the relationship between schooling, income and occupational stratum.

${ }^{2}$ See Featherman, Jones and Hauser (1975) and Erikson and Goldthorpe (1992). in economic growth and the ability of the State to cope with the new international conditions, and in heightened economic and social inequality. In Mexico, there have been numerous studies into the effects of this shift on poverty levels and the inequality of income distribution (Boltvinik and Hernández Laos, 1999; Cortés, 2000; Rubalcava, 1999). Population and job creation trends are also known (CONAPO, 1999 and 2000; Tuirán, 2000; Escobar, 2000a). What has been virtually ignored until now is the relationship between economic reform and the degree of equity in the social mobility system.

Given the lower growth and large economic fluctuations that have been seen, it is essential for this analysis to be conducted with a methodology that can measure structural mobility, which is the outcome of population changes, economic growth and job creation in each occupational stratum.

The present analysis is conducted in two stages. First, it establishes the general level of incorporation of individuals into each social class or stratum, i.e., absolute opportunities for mobility, which are strongly influenced by the level of economic and demographic growth. Second, it uses the analysis of relative opportunities to establish the level of inequality in competition conditions, controlling for economic and demographic developments. This is what may properly be called "endogenous" analysis of the social mobility system. In the debate, changes in participation levels or in occupational distribution are often confused with changes in inequality conditions in the competition to attain the highest socio-occupational positions. For example, there are now more women than formerly in the labour market, both in high positions and generally, but this does not in itself mean that the social mobility system has "opened up"; in other words, the fact that more women are reaching high positions does not allow any inferences at all to be drawn about the conditions and barriers they encounter on the way, since far more women are now competing than before. Thus, there is a need for a specific analysis to show the evolution of inequality in the competition between women of different classes and between women and men, i.e., an analysis of relative opportunities by class and gender. 
This is the aim of the present study, which explores the way mobility systems have become more or less open as Mexican cities have moved from import substitution industrialization (ISI) to a period of crisis, adjustment and uncertainty (transition phase) followed finally (up to the present) by a third period which we call the "restructuring" period. For our purposes, and in this text, analysis of the social mobility system at the "genotype" level is defined as the analysis of relative opportunities for social mobility by class and gender and, more specifically, as the analysis of odds and of odds ratios, respectively, in all social groups in relation to the highest class in the occupational structure.

The analysis is based on a random sample of households and individuals in six Mexican cities (Mexico City, Guadalajara, Monterrey, Mérida, Veracruz and Córdoba-Orizaba), conducted between July and September 1994, which was a core component of the "Género, edad, familia y trabajo" study. Although it has its limitations, it is the broadest survey of social mobility to have been conducted in Mexico and, in view of its coverage, we believe that it reflects the general conditions of the urban social structure.

Social mobility systems were studied in Mexico during the 1960s and early 1970s. In these studies, the analysis of social mobility was related to the rapid urbanization of Mexico and the unequal participation of the population in the labour and employment modernization process that took place then: the expansion of the State machinery and social services, and of service functions in companies (Balán, Browning and Jelin, 1973; Muñoz, De Oliveira and Stern, 1977; Contreras, 1978).

The main contributions of these studies to our subject are as follows: i) they establish the inequality in individual attainments by class of origin; ii) they highlight the importance for attainment levels of migratory origin and "exposure" to the urban environment, and iii) they allow a distinction to be drawn between structural social mobility and circular mobility.

They have four limitations, however: i) they deal with just one city, Mexico City or Monterrey, and are not comparable between themselves; ii) they deal only with men; iii) they do not provide an analysis of changes in the social mobility system as such, i.e., in the "endogenous" or inequality characteristics of social mobility, and iv) they do not systematically reflect the heterogeneity of occupations, strata and social classes.

These limitations determine the main challenges to be met by research into social mobility today. The greatest challenge, however, will be to determine how and by how much the basic components of social mobility have changed, so that we have available a medium-term historical diagnosis of the increasing or decreasing openness of stratification and mobility systems in our countries. This is essential, given the depth of economic and institutional change in the societies of Latin America.

The weight of Mexico City and other large cities in the country has diminished, and it is medium-sized cities that are now the most dynamic. For this reason the analysis, while it cannot neglect the largest cities, also needs to include medium-sized ones; this would mean, in principle, that the findings could be treated as applicable to the urban system as a whole.

Women need to be included. Given the doubling of women's participation rates, economic restructuring (which may affect men more than women) and the growth in households headed by women (Payne and Abbott, 1990), it is unacceptable for class or social stratum to be determined predominantly by the employment of male heads of households.

The analysis presented below seeks to overcome these limitations. Its main contribution is to establish levels of change in absolute and relative opportunities for social mobility as one economic phase succeeds another, and the interaction between the growing participation of women in employment, on the one hand, and the general conditions of the mobility system, on the other. ${ }^{3}$

\footnotetext{
${ }^{3}$ Many problems still remain to be addressed in future studies, however. Two may be mentioned here: the economic reforms have not reduced, but entrenched, the structural heterogeneity of employment in Latin America, where a sector of modern privateand public-sector employment governed by bureaucratic rules exists side by side with ever-growing numbers of people in informal occupations (or the black economy) or in own-account work. Should social mobility analyses create at least two mobility systems, each identified with an employment sector? How should this diversity be recognized? Is there enough movement between these sectors for it to be possible to speak of a single system? Is one of the two a "trap" for those entering it, or are these both "open" sectors, meaning that they can be taken together as a single system? Another challenge for analysis is the growing scale of occupational and social exclusion in Latin America, transcending occupation-centred analysis.
} 


\section{II}

\section{Aims and hypotheses of the analysis}

The purpose of this analysis is to measure changes in opportunities of access to higher-level occupations in Mexican cities. The first axis in this measurement is social class, ${ }^{4}$ and for this a specific stratification has been designed. The second axis is time. The analysis looks at the careers of individuals who began working before 1982, between 1982 and 1988, and between 1988 and 1994, and contrasts the relative opportunities of individuals from different social classes in the import substitution industrialization period, in the transition years from 1982 to 1988 , and in the subsequent economic restructuring. A further variable is brought in, namely gender, to establish whether women are now competing under the same conditions of inequality (of gender and class) as before 1982 .

Empirical analysis of these phenomena is vital, since opposing forces were acting on mobility systems during these periods. When growth in modern and nonmanual occupations stagnates generally, some privileged groups can bring into play mechanisms that restrict entry to them, so that the system will tend to close up and inequality of access to intensify. Conversely, when recruiting for such positions the private sector and State will prefer people who demand less in the way of wages and security, which may lead to greater openness (and a corresponding diminution of privilege). Social institutions that create a degree of equity (staple food subsidies, free education, universal health services) are also undergoing restructuring, although it cannot be said that their influence is clearly diminishing in Mexico. Price subsidies for food and utility services have been dismantled. Public education services have expanded their coverage. "Open" health services have done the same but the best-developed system, the employment-linked health services provided by the Mexican Social Security Institute (IMSS), now covers a smaller proportion of the workforce than before, as informal employment has increased. In other words, so long as these systems

\footnotetext{
${ }^{4}$ We are aware of the ambiguity of the term "social class" when used to refer to social conglomerates united by educational and income levels and their position in the social scale, rather than production relationships. For this reason, the term "social stratum" will be used in some cases. It should be noted, though, that the two terms are used synonymously in this text.
}

work, they will tend to promote equity and open up the social mobility system; but if they go into crisis, this system may tend to close up. Lastly, the rapid growth of "targeted" social health and education programmes will also need to be evaluated for their effects on the equity of social mobility, although their effects are not yet observable. ${ }^{5}$

Households partially offset the decline in real wages by increasing the participation of women and young people in the workforce (González de la Rocha and Escobar, 1986; González de la Rocha, 1988; De Oliveira, 1988; Selby, Murphy and Lorenzen, 1990; De Barbieri, 1989; Cortés and Rubalcava, 1991; Tuirán, 1993; González de la Rocha, 1994, pp. 136 to 139; Escobar and González de la Rocha, 1995; HernándezLicona, 1997, pp. 547-560). At 39\%, women's participation in employment is now about double what it was in 1979 (García and De Oliveira, 1994; INEGI, 2002). If this intensification of employment is accompanied by a reduction in years of education among poor women and young people, then greater inequality could result. But if the increase is distributed equally among all social classes, there might be no change.

Besides the interplay of opposing forces, changes in the nature of the labour market are likely to be found in the periods examined. We shall deal only with two. First, it is possible that what is meant by reaching the "top" of the occupational hierarchy may have changed. In other words, it may have happened that the everincreasing power of employers has resulted in these higher positions being "downgraded" in relation to lower ones, so that access to them is less remunerative than before, at least in one sector of employment (the public sector, for example). Reyes Heroles (1983) noticed the beginnings of a process of this type as early as the

\footnotetext{
5 In Mexico, the Progresa programme (now the Oportunidades programme) began operating in 1997 in deprived rural communities and only included poor urban areas in 2001 and 2002. This programme makes cash payments to poor families $(4,240,000$ beneficiary families in 2002), on condition that they send their children to school and comply with health programmes (Escobar, $2000 \mathrm{~b}$ and 2000c). Given that this support is targeted on poor households, the impact of the programme should consist in: i) a rapid rise in educational levels among the poorest, and ii) a diminution of inequality in school achievement between the poor and the non-poor.
} 
second half of the 1970s, when the income gap between manual and non-manual employment narrowed perceptibly. Solís (2002) made the same observation in a recent analysis of occupational mobility and income in Monterrey. Secondly, it may have happened that stagnation in the non-manual and higher occupations has resulted in a more extended career structure, i.e., in a multiplication of the intermediate stages between the beginning and culmination of a career. This may mean that careers commence at a lower level, although some of those setting out from lower positions than earlier cohorts may also reach the highest positions, only later in their careers.

To sum up, in periods when the economic model is changing there are a wide range of forces acting in different directions upon the social and employment structure, and some of these forces alter the nature of this stratification. But given the right sources and methods, this need not prevent us from ascertaining the direction and significance of economic change in terms of greater or lesser openness in the social employment structure.

\section{III}

\section{Methodology and model of analysis}

As has already been stated, this study seeks to ascertain only how and to what extent patterns of labour mobility have changed, for both men and women, in the phases through which the Mexican economy has passed during the last five decades. The aim is to find out whether there have been changes in mobility patterns by class and gender and, if so, what the direction of these changes has been.

With this aim in mind, one of the main elements in the "Género, edad, familia y trabajo" project is analysed. These are the results of a wide-ranging questionnaire conducted with a random sample of 11,800 households in six Mexican cities (Mexico City, Guadalajara, Monterrey, Mérida, Veracruz and Córdoba-Orizaba), which was answered by 25,000 people aged over 18. It included questions on the migratory, educational, occupational and family history of both the respondent (also called "ego") and the person who was the breadwinner ${ }^{6}$ when the respondent was 14. Between July and September 1994, the questionnaire was appended to the National Urban Employment Survey (ENEU) conducted each quarter by the National Institute of Statistics, Geography and Information (INEGI) in 44 Mexican cities. Given the nature of the research, particular care was taken to

\footnotetext{
6 By "breadwinner" (responsable económico) is meant the person who made the main contribution to the respondent's subsistence when the latter was 14 . In over $80 \%$ of cases this is the father; it is the mother in less than $10 \%$; the balance is made up of other adults and the actual respondent. The breadwinner, male or female, is regarded as the respondent's predecessor for the purpose of assessing the respondent's social mobility.
}

avoid the pro-male biases that characterize traditional social mobility surveys. Details of the design and results can be found in Escobar (1996).

Six occupational strata were used to analyse social mobility. Ranked from top to bottom, they are as follows:

(I) Professionals, managers and executives and employers of more than five workers.

(II) Technical and white-collar workers.

(III) Small employers and non-professional ownaccount workers.

(IV) Skilled workers in industry and formal workers in services.

(V) Unskilled workers in industry and informal workers in services.

(VI) Ejidatarios (holders of shares in common lands), small rural landowners and labourers. ${ }^{7}$

Table 1 shows that an informant's average income by occupational stratum declines systematically from the top to the bottom of the ranking. ${ }^{8}$

The monthly income of professionals, managers and executives and employers of more than five workers (stratum I) is 3.25 that of technical and whitecollar workers (stratum II) and 3.3 times the average; from the second stratum downward the decline is

\footnotetext{
${ }^{7}$ In this urban sample, few respondents belonged to this agricultural employment stratum; the calculations include it, however, because it is very significant as the breadwinner's occupation $(\mathrm{N}=2.255)$ and the inequality encountered is significant and consistent with other studies.

${ }^{8}$ All the tables in this article are based on material obtained from the survey carried out for the "Género, edad, familia y trabajo: reestructuración de la sociedad urbana en México" project.
} 
TABLE 1

Mexico (6 cities): Occupational stratum and average income of survey respondents

\begin{tabular}{lc}
\hline Stratum & $\begin{array}{c}\text { Monthly income from main occupation } \\
\text { (in 1994 dollars) }\end{array}$ \\
\hline I & 1403.1 \\
II & 430.6 \\
III & 404.3 \\
IV & 274.8 \\
V & 245.0 \\
VI & 201.8 \\
& \\
Total & 427.6
\end{tabular}

Source: Modules appended to the National Urban Employment Survey (ENEU), July-September 1994.

regular and even. The polarization revealed by the table reflects the unequal distribution of income in Mexico.

At the same time, educational levels fall systematically down the occupational scale.

The unemployed are not included in this analysis. They lack the attributes needed to place them in the stratification; besides, it would be wrong to assign the same place to an unemployed professional as to an unemployed farmer. Their social strata remain different even though they are both unemployed, because they belong to social groups normally defined by their previous occupations. However, analysis of movements into and out of unemployment and their impact on subsequent occupational attainment, among both men and women, is of growing importance in Latin America (Cerrutti, 2000a and 2000b).

The following points should be made about this table: i) there is a clear gap in educational levels between those in the top stratum (I) and the rest, the distribution in this group being concentrated in full and postgraduate higher education; ii) technical and whitecollar workers are characterized by the predominance of secondary and higher educational levels, and iii) the lower levels of education predominate from the third stratum downward.

This paper looks at mobility between the occupational stratum of the informant's first job and that of the breadwinner in the household when the informant was 14 , i.e., intergenerational mobility up to the first employment of men and women from all urban social classes.

In measuring social mobility it must be remembered that in a sample of people whose ages range from 18 to over 97, a distinction has to be drawn between changes in occupational stratification resulting from the spectrum of opportunities made available by the economic structure, i.e., what is commonly termed structural mobility, and changes influenced by an individual's class of origin. For example, it is well documented that the growth of services in the Mexican economy in the 1970s increased employment opportunities for women; consequently, some of their social mobility was due to this widening of the opportunities provided to them by changes in the economic structure. Thus, we need a method that can measure inequality in the attainments of different people and not just their absolute mobility, whether upward or downward.

The Mexican economy is usually viewed as having passed through three periods in the last five decades, namely: the stabilizing development period, which ended with the 1982 crisis, although its problems began in the early 1970s and manifested themselves dramatically in the 1976 crisis; the transition period, when the policy approaches of the import substitutionbased development period coexisted with those of the third period; and the last phase, that of structural change, whose commencement is dated to 1988 and which might be characterized by the formula "more market and less State" (Cortés, 2000).

If each of these three periods is characterized by economic structures that are qualitatively different, patterns of urban occupational mobility should display significant alterations. For example, it is known that one of the characteristic features of the import substitution model (phase I) was strong growth in typically middleclass jobs; meanwhile, the keynote of structural change (phase III), at least up until the early twenty-first century, has been rising poverty and greater social polarization worldwide (World Bank, 2000; UNRISD, 2000, pp. 11-13). Mexico has been no exception (Hernández Laos, 2001, pp. 56-67 and 98-119).

Taking account of the three phases through which the Mexican economy is considered to have passed during the second half of the twentieth century, the sample was divided into three by the age of respondents: up to $26 ; 27$ to 35 ; and 36 and over. These three categories place the breadwinner either in the same period as the respondent, or in the one immediately preceding, as table 3 shows (it must be remembered that the information on the breadwinner relates to the year when the respondent was 14 , and it can be used for analysis between and within periods). In theory, the study provides information on social mobility within each phase, leaving structural mobility constant; this control will only be partial, however, as 
Mexico (six cities): Occupational strata and education levels ${ }^{a}$ (Percentages and cases)

\begin{tabular}{|c|c|c|c|c|c|c|c|c|c|c|c|c|c|}
\hline Stratum & $\begin{array}{c}\text { No } \\
\text { schooling }\end{array}$ & $\begin{array}{l}\text { Incomplete } \\
\text { primary }\end{array}$ & $\begin{array}{c}\text { Complete } \\
\text { primary }\end{array}$ & $\begin{array}{l}\text { Incomplete } \\
\text { secondary }\end{array}$ & $\begin{array}{l}\text { Complete } \\
\text { second. }\end{array}$ & $\begin{array}{l}\text { Incom. } \\
\text { upper. }\end{array}$ & $\begin{array}{c}\text { Complete. } \\
\text { upper }\end{array}$ & $\begin{array}{l}\text { Incom. } \\
\text { higher }\end{array}$ & $\begin{array}{c}\text { Complete } \\
\text { higher }\end{array}$ & Postgr. & No data & Total & $\begin{array}{l}\text { Total } \\
\text { cases }\end{array}$ \\
\hline I & 0.0 & 0.6 & 2.0 & 0.6 & 4.8 & 1.2 & 3.0 & 5.2 & 71.7 & 10.9 & 0.0 & 100.0 & 1280 \\
\hline II & 0.9 & 3.9 & 10.3 & 5.3 & 37.6 & 6.7 & 11.6 & 8.1 & 15.1 & 0.7 & 0.0 & 100.0 & 5657 \\
\hline III & 9.3 & 18.9 & 26.4 & 6.5 & 19.7 & 3.4 & 4.6 & 3.5 & 7.0 & 0.9 & 0.0 & 100.0 & 3251 \\
\hline IV & 3.7 & 14.6 & 30.0 & 9.6 & 28.4 & 6.2 & 4.9 & 1.5 & 1.1 & 0.0 & 0.0 & 100.0 & 3567 \\
\hline $\mathrm{V}$ & 6.3 & 18.3 & 29.8 & 8.2 & 26.2 & 4.3 & 4.3 & 1.8 & 0.8 & 0.0 & 0.0 & 100.0 & 2367 \\
\hline VI & 4.0 & 22.0 & 26.0 & 10.0 & 24.0 & 0.0 & 0.0 & 10.0 & 4.0 & 0.0 & 0.0 & 100.0 & 50 \\
\hline Total & 3.9 & 11.2 & 20.1 & 6.5 & 27.6 & 5.1 & 6.9 & 4.6 & 12.7 & 1.3 & 0.0 & 100.0 & 16172 \\
\hline
\end{tabular}

Source: Prepared by the authors using data from CIESAS/INEGI (1996).

a In Mexico the primary level includes six years of basic schooling, the secondary level three years more, and the upper (medio superior) level a further three. "Higher" is equivalent to university.

TABLE 3

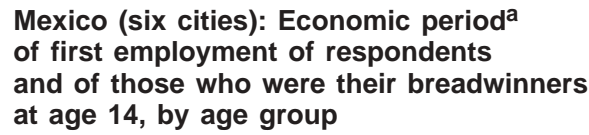

\begin{tabular}{lcc}
\hline Age group & Respondent & $\begin{array}{c}\text { Predecessor } \\
\text { (respondent's father } \\
\text { or breadwinner) }\end{array}$ \\
\hline 18 to 26 & III, II & III, II \\
27 to 35 & II, I & I \\
36 and over & I & I \\
\hline
\end{tabular}

Source: Prepared by the authors using data from CIESAS/INEGI (1996).

a Period I, stabilizing development, 1982 and earlier; period II, transition, between 1983 and 1987, and period III, structural change, between 1988 and 1994 .

b The "father or breadwinner" category refers to the father (if he lived with the respondent) or, in his absence, whoever made the main financial contribution to the domestic unit where the respondent lived at the age of 14 . Among those entering the labour market in period I, this was the father in $80 \%$ of cases. Among those entering it later, it was the father in $91 \%$ of cases.

adjoining intervals overlap. ${ }^{9}$ This imprecision in the empirical cut-off points needs to be dealt with for accurate results to be obtained.

For the purposes of the present study, all members of the first age group are classified as belonging to economic period III (structural change), those in the second age group are assigned to period II, and those

\footnotetext{
${ }^{9}$ The classification is not based on the date of first employment but on age in each of the periods. Thus, for example, the young cohort was aged between 12 and 20 when the restructuring period began in 1988, so that the great bulk of these people began their careers after that time.
}

in the third group to period I. This classification of age groups in the historical periods was used to produce the transition matrices that can be found in the appendix. The calculations provide information about the proportion of "successors" ending up in each of the six strata, given the strata of their "predecessors". These data are quite informative when there have been no changes in the opportunity structure, or when change has been gradual and the observation time short, or when the economic structure has not undergone significant changes during the period analysed. None of these situations holds for Mexico in the second half of the twentieth century, so the likelihood of mobility in the country depends not just on the stratum of the breadwinner, but on structural changes as well.

It has already been noted that dividing the observations into three subsets defined by respondent age only partially measures the effect of structural mobility since, as was seen in table 3 , these combine some of the periods through which the Mexican economy has passed. Mobility studies usually control for structural mobility by calculating the odds ratio (R),${ }^{10}$ odds being the quotient between the probability of moving and not moving between strata $i$ and $j$.

\footnotetext{
${ }^{10}$ The idea is that, in principle, structural mobility should provide more opportunities at all ages, so that the odds should increase proportionately; i.e., the odds of all age groups should increase. Suppose that during a particular period, for example, for every child of professionals descending four remained in class I, while for every two children of office workers only one reached this class, and the odds doubled in both cases because of a change in the production structure, i.e., increased to eight and two, respectively. In this example both odds rise, but the ratio between them stays constant. This statistical artifice annuls the effect of the structural factor, since the incidence on the probability of the numerator is cancelled out by that operating on the denominator.
} 
Now, given the social class of origin, as measured by the occupation of the breadwinner when the respondent was 14 , it is possible to find out which is the modal class of destination, i.e., the most probable. In the language of descriptive statistics, this category is a central tendency indicator, and there is one for each line of the transition matrix. If it is known that the predecessor was situated

\section{IV}

\section{The results}

\section{Changes in general intergenerational mobility to first employment}

This article only analyses intergenerational social mobility between the respondent's first job and the occupation of his or her father or breadwinner when he or she was 14. Naturally, most of those surveyed were in different jobs or occupations by the time of the interviews. Nonetheless, the decision to confine the study to mobility at the time of first employment allows a partial estimate to be reached of the effects of differing career length between young and old. In this way, we were able to contrast fairly comparable points in the careers of all the individuals analysed, irrespective of age.

Table 4 shows the mobility opportunities associated with the six social strata during the import substitution industrialization ("ISI") period, the transition ("mixed") period and the economic restructuring ("restructuring") period. The odds given in the body of the table indicate the opportunities for individuals in the sample to reach stratum I, depending on their stratum of origin and their cohort. ${ }^{11}$

The three series of odds show, as was to be expected, that opportunities for entering stratum I decrease as we descend from the top to the bottom of the stratification. Social mobility prospects do not change significantly in the first two periods, but in

${ }^{11}$ The definition of odds is $M_{i j}=M_{i j}=\frac{P_{i j}}{1-P_{i j}} i, j=1,2,3,4,5,6$, where $P_{i j}$ symbolizes the probability of a person having a stratum $j$ job, given that the breadwinner was in stratum $i$ when the respondent was 14 . in stratum $i$, the mode indicates the most likely destination for the respondent in the occupational hierarchy. Following the rules of elementary statistics, the transition probabilities, the odds and their ratios, which can be regarded as central tendency measures, were supplemented by entropy, which is a dispersion measure for non-metric variables (Theil, 1972).

the third they decline sharply at all social levels. These results show that economic restructuring in Mexico, at least in its early stages, reduced opportunities for occupational mobility by comparison with the options made available by the previous economic model.

To form an idea of the degree to which absolute opportunities for labour mobility had diminished, we established for each stratum the ratio between the odds in the import substitution and transition periods in relation to those in the restructuring period; this yields a single, simple number that gives an idea of the effect the change in model has had on mobility for the different social classes.

As table 5 shows, the decline in opportunities is greater among those from the two lowest classes, although it is also substantial among the higher classes. Economic restructuring diminished opportunities for social mobility among all strata, but this effect was far more marked in the lowest classes. It should be noted that the reduction in opportunities left employers of up to five workers and non-professionals virtually unaffected. This is an interesting finding that could guide future research into the informal sector, and it is worth asking whether it is related in any way to the marked growth of this sector in the last two decades. The central characteristics revealed by the table show that the tendency is not linear by social stratum of origin (it is more like a "U"). Furthermore, the fact that the greatest decline is found among the most deprived sections of society indicates an increase in the inequality of opportunity.

In this analysis, as was explained in the previous section, we have included a dispersion measure for those leaving each social stratum of origin, called 
TABLE 4

Mexico (six cities): Absolute opportunities for moving into stratum I

\begin{tabular}{llrr}
\hline \multicolumn{2}{l}{ Social stratum of predecessor } & ISI $^{\mathrm{a}}$ & Transition $^{\text {Restructuring }}$ \\
\hline I & Professionals, managers and executives, employers of more than 5 workers & 0.218 & 0.230 \\
II & Technical and white-collar workers & 0.051 & 0.084 \\
III & Small employers and non-professional own-account workers & 0.021 & 0.051 \\
IV & Skilled workers in industry and formal workers in services & 0.014 & 0.020 \\
V & Unskilled workers in industry and informal workers in services & 0.013 & 0.011 \\
VI & Ejidatarios, small rural landowners and labourers & 0.011 & 0.015 \\
\hline
\end{tabular}

Source: Prepared by the authors using data from CIESAS/INEGI (1996).

a Import substitution industrialization.

TABLE 5

Mexico (six cities): Absolute opportunities for moving into stratum I, taking the restructuring period as the base

\begin{tabular}{llrl}
\hline Social stratum of predecessor & ISI & Transition & Restructuring \\
\hline I & Professionals, managers and executives, employers of more than 5 workers & 2.591 & 2.744 \\
II & Technical and white-collar workers & 1.985 & 2.000 \\
III & Small employers and non-professional own-account workers & 1.324 & 1.000 \\
IV & Skilled workers in industry and formal workers in services & 2.349 & 1.000 \\
V & Unskilled workers in industry and informal workers in services & 3.021 & 1.932 \\
VI & Ejidatarios, small rural landowners and labourers & 4.936 & 3.626 \\
\hline
\end{tabular}

Source: Prepared by the authors using data from CIESAS/INEGI (1996).

entropy. ${ }^{12}$ This measurement is the only one in our analysis that does not relate to attainment of the highest social stratum, but to the dispersion of those from a given category among all destination positions. In table 6 we present the results of the standardized entropy calculation. The values of this measure range between 0 and 1; the entropic index of a stratum tends to zero when all successors end up in one and the same stratum (albeit not necessarily that of the predecessor); when this happens, the transition matrix has to be examined to identify which that destination was. If the origin has no influence whatever on the destination, the index will have the value 1 ; in this case all destinations are equally likely to be reached from the starting point of a given stratum.

${ }^{12}$ For the particular case being analysed, entropy $H$ is defined as: $H_{i}=\sum_{j=1}^{j=6} P_{i j} \operatorname{Ln} \frac{1}{P_{i j}} i=1,2,3,4,5,6$.

The entropy is normalized by limiting its range to the interval 0 to $1\left(H_{N}\right)$; for this $H_{i}$ is divided by the maximum theoretical value $\left(H_{M}\right)$, which in this case is equal to $\operatorname{Ln} 6$. Consequently, $H_{N}$ responds to the following expression: $H_{i N}=\frac{H_{i}}{H_{M}} i=1,2,3,4,5,6$.
The information contained in table 6 supplements that of the earlier tables; these confined themselves to showing what happens to social mobility whose destination is the top of the stratification, whereas this one synthesizes the opportunities for mobility from any origin to any destination.

The data in this table yield the conclusion that during the transition years, as compared with the import substitution industrialization stage, the social mobility options of the first four strata (I to IV) diminished and those of unskilled manual, itinerant and "other" workers increased. Conversely, when we compare the restructuring period with the ISI period it transpires that social mobility fell for all social classes without exception.

Against the background delineated so far (social mobility in the ISI period, changes in mobility that varied by stratum during the transition period and a clear general reduction in mobility opportunities during restructuring, accompanied in particular by a lessening of opportunities to reach the top), it must now be asked which was the class whose members bore the brunt of the changes. Asking this is equivalent to focusing the inquiry on social mobility opportunities, taking changes 
TABLE 6

Mexico (six cities): Standardized entropic index of absolute opportunities for mobility

\begin{tabular}{|c|c|c|c|c|}
\hline \multicolumn{2}{|c|}{ Social stratum of predecessor } & \multirow{2}{*}{$\begin{array}{c}\text { ISI } \\
0.770\end{array}$} & \multirow{2}{*}{$\begin{array}{c}\text { Transition } \\
0.686\end{array}$} & \multirow{2}{*}{$\begin{array}{c}\text { Restructuring } \\
0.692\end{array}$} \\
\hline I & Professionals, managers and executives, employers of more than 5 workers & & & \\
\hline II & Technical and white-collar workers & 0.733 & 0.666 & 0.685 \\
\hline III & Small employers and non-professional own-account workers & 0.914 & 0.848 & 0.810 \\
\hline IV & Skilled workers in industry and formal workers in services & 0.833 & 0.774 & 0.762 \\
\hline $\mathrm{V}$ & Unskilled workers in industry and informal workers in itinerant services & 0.749 & 0.761 & 0.733 \\
\hline VI & Ejidatarios, small rural landowners and labourers & 0.837 & 0.849 & 0.795 \\
\hline
\end{tabular}

Source: Prepared by the authors using data from CIESAS/INEGI (1996).

TABLE 7

Mexico (six cities): Relative opportunities for reaching stratum I

\begin{tabular}{|c|c|c|c|c|}
\hline \multicolumn{2}{|c|}{ Social stratum of predecessor } & \multirow{2}{*}{$\begin{array}{c}\text { ISI } \\
1.000\end{array}$} & \multirow{2}{*}{$\begin{array}{c}\text { Transition } \\
1.000\end{array}$} & \multirow{2}{*}{$\begin{array}{c}\text { Restructuring } \\
1.000\end{array}$} \\
\hline I & Professionals, managers and executives, employers of more than 5 workers & & & \\
\hline II & Technical and white-collar workers & 0.233 & 0.222 & 0.305 \\
\hline III & Small employers and non-professional own-account workers & 0.096 & 0.086 & 0.187 \\
\hline IV & Skilled workers in industry and formal workers in services & 0.063 & 0.049 & 0.069 \\
\hline V & Unskilled workers in industry and informal workers in services & 0.058 & 0.066 & 0.050 \\
\hline VI & Ejidatarios, small rural landowners and labourers & 0.050 & 0.043 & 0.026 \\
\hline
\end{tabular}

Source: Prepared by the authors using data from CIESAS/INEGI (1996).

of period into account; this analysis will yield what is usually called the "genotype" of the social mobility system.

The odds ratio ${ }^{13}$ can be used to study mobility controlling for the effects upon it of structural mobility, i.e., that portion of the changes of stratum that arises from alterations in the economic structure. This is what we call relative opportunity analysis, i.e., the analysis of competition conditions in the social mobility system, irrespective of economic and demographic fluctuations.

Table 7 shows the evolution of relative opportunities for people from different strata, irrespective of the absolute level of movement into class I, and allows these opportunities to be analysed between any pair of social classes, although the reference variable is always the opportunity ratio of those from stratum I. Focusing on the economic restructuring phase, as compared with the import substitution phase, it transpires that the disproportion between the opportunities of the lowest classes and

13 The odds ratio is defined as $R_{i 1}=\frac{M_{i 1}}{M_{11}}=\frac{\frac{P_{i 1}}{1-P_{i 1}}}{\frac{P_{11}}{1-P_{11}}} \quad i=1,2,3,4,5,6$. those of people from the highest class increases; this outcome was to be expected since, as was seen earlier, the situation worsened most in the lowest classes.

The odds ratios of the second and third strata increased significantly in the restructuring phase by comparison with the ISI phase. Thus, technical and white-collar workers, along with employers of up to five workers and non-professionals, who did not escape the general decline in mobility opportunities, did see a relative improvement in their prospects of reaching the pinnacle of the occupational structure. As can be seen, the ratio of stratum III almost doubled, because opportunities diminished less there than in stratum I, and the stratum II ratio rose significantly.

Thus, changes in relative opportunities for reaching stratum I between the ISI and restructuring phases can be divided into three: relative inequality of opportunity declines among those from the first three social classes, holds fairly steady for class IV and increases in classes V and VI, particularly the latter. Thus, rising up from farming to stratum I becomes practically impossible: during the ISI period, inequality was 1 over 0.05 , or 20 times; during the restructuring period, the ratio was 1 over 0.026 , or approximately 40 times; this indicates that those from stratum I have 40 times as much opportunity to reach that stratum as 
those from an agricultural background or, in other words, that the relative opportunities of the latter have halved.

\section{Intergenerational mobility by gender}

The research done in Mexico shows a significant and steady rise in female participation in the workforce. The question, then, is what kinds of employment women end up obtaining in a context of greater rigidity in social mobility.

The rise in female employment could be due both to a strategy by households to cope with the successive crises through which the country has passed since the 1980s (González de la Rocha and Escobar Latapí, 1986) and to a cost-cutting strategy on the part of businesses, if we consider that women are usually paid less than men for doing the same jobs with the same qualifications (Pacheco and Parker, 1996). If this were the case, we should observe barriers to the social advancement of women. At the same time, research has shown that the increase in educational levels among women (García and De Oliveira, 1994) has been one of the forces driving this growth. Assuming a relationship between years of education and social stratum, these processes should translate into social advancement. What effects have these changes in workforce participation had on social mobility by gender?

Table 8 shows the odds of reaching stratum I for people from all strata, by cohort and sex. The odds in the panel where the information on women is displayed indicate that women from households whose breadwinner was in any of the three upper strata (I to III) experienced a significant rise in their opportunities for social mobility in the transition period, as compared to the ISI period. However, this increase was uneven: the odds rose by a factor of 8.4 for women from stratum I, by 3.1 for those from stratum II and by just 1.6 for those from stratum III. In the social layers at the base of the pyramid there were no significant changes during the period. Women from domestic units headed by skilled and unskilled manual workers, and those from rural households, experienced no significant change in their almost non-existent opportunities for reaching the pinnacle of society.

The economic restructuring years were accompanied by a significant reduction in the social mobility options of women from strata I, III and IV, while in the bottom two there were once again no significant alterations. Only the daughters of technical and white-collar workers (II) kept the same odds as in the transition years. More in-depth studies will be needed to understand this behaviour.

The shift from the ISI model to the transition model was accompanied by an increase in the opportunities for women from the higher classes to reach stratum I (or remain there), and the shift from transition to restructuring was marked by a significant decline in the odds, with the exception of the daughters of technical and white-collar workers already referred to. Since the growth was greater than the reduction,

TABLE 8

Mexico (six cities): Absolute opportunities for moving into stratum I, by gender

\begin{tabular}{|c|c|c|c|c|c|}
\hline \multicolumn{3}{|c|}{ Social stratum of predecessor } & \multirow[t]{2}{*}{ ISI } & \multirow[t]{2}{*}{ Transition } & \multirow[t]{2}{*}{ Restructuring } \\
\hline Men & I & Professionals, managers and executives, employers of more & & & \\
\hline & II & $\begin{array}{l}\text { than } 5 \text { workers } \\
\text { Technical and white-collar workers }\end{array}$ & $\begin{array}{l}0.332 \\
0.071\end{array}$ & $\begin{array}{l}0.231 \\
0.071\end{array}$ & $\begin{array}{l}0.071 \\
0.023\end{array}$ \\
\hline & III & Small employers and non-professional own-account workers & 0.020 & 0.008 & 0.016 \\
\hline & IV & Skilled workers in industry and formal workers in services & 0.014 & 0.015 & 0.007 \\
\hline & V & Unskilled workers in industry and informal workers in services & 0.021 & 0.021 & 0.007 \\
\hline & VI & Ejidatarios, small rural landowners and labourers & 0.013 & 0.011 & 0.000 \\
\hline \multirow[t]{6}{*}{ Women } & I & $\begin{array}{l}\text { Professionals, managers and executives, employers of more } \\
\text { than } 5 \text { workers }\end{array}$ & 0.026 & 0.218 & 0.102 \\
\hline & II & Technical and white-collar workers & 0.009 & 0.028 & 0.029 \\
\hline & III & Small employers and non-professional own-account workers & 0.023 & 0.038 & 0.015 \\
\hline & IV & Skilled workers in industry and formal workers in services & 0.010 & 0.008 & 0.002 \\
\hline & V & Unskilled workers in industry and informal workers in services & 0.000 & 0.005 & 0.000 \\
\hline & VI & Ejidatarias, small rural landowners and labourers & 0.006 & 0.007 & 0.006 \\
\hline
\end{tabular}

Source: Prepared by the authors using data from CIESAS/INEGI (1996). 
women in strata I and II improved their mobility options over the three periods.

Women descended from small employers and technical workers, whose options expanded significantly in the transition period, saw them contract severely when economic restructuring took place, so that they ended the period with a large reduction in the odds of their rising up to the highest class. Those from stratum V saw virtually no change, while those from IV saw their already meagre options diminish further.

The transition did not alter social mobility opportunities for men, except for those with predecessors in strata I and III, whose odds fell by $30 \%$ and $60 \%$, respectively. Once the new economic model was consolidated, mobility options declined markedly in all strata except that of small employers and nonprofessional own-account workers, for whom the decline was small. Does this have some link with the expansion of the informal sector?

Owing to the movements described for men and women, it transpires that opportunities for reaching stratum I have altered in ways that differ greatly by gender. Whereas tables 4 to 7 , which appear in the previous section, only showed insignificant changes between the first and second phases, table 8 shows that for men the situation worsened in an almost linear fashion, while for women in the higher classes the situation improved very significantly from the first period to the second and then worsened markedly from the second to the third. The "stability" in social mobility opportunities between the ISI period and the transition period that is observed in tables 4 to 7 is made up of a worsening of opportunities for men and an improvement for women. From the second period to the third, the situation worsened for both sexes.

Table 9 compares the mobility opportunities of the first two phases with those of the restructuring phase. For men from stratum $\mathrm{I}$ the fall is almost linear and for those from stratum II there is a decline followed by a slight recovery, while for the rest there is greater stability from the first to the second phase and a marked reduction in the third.

In any event, the overall result for men is a loss, while the situation for women has been far more variable. All in all, opportunities for women from the first two strata have increased very significantly. Those from strata III and IV have experienced a loss of opportunities, and those whose predecessors were in agriculture have seen virtually no change.

The gender-specific entropic index adds to the analysis of the previous section, which did not distinguish this variable. The dispersion of men in the destination strata is quite high, indicating that males of any social status have "similar" probabilities of ending up in any stratum. Furthermore, entropy changes are small, meaning that options for moving between the different strata seem to be independent of the period being passed through by Mexican society at the time.

During the transition years, women's opportunities for social mobility diminished by comparison with the previous phase in all strata, except among those from households headed by itinerant and unskilled manual workers. When the restructuring period was over the mobility prospects of women diminished again in all classes except the highest one. Women in strata I and $\mathrm{V}$ escaped this tendency, ending up with higher entropy in the restructuring phase than in the IsI stage. Overall, table 10 indicates that inequality by origin is probably lower among young men and higher among young women.

Table 11 shows the odds ratios of movement into stratum I by origin and gender, i.e., the inequality of opportunities of access to stratum I within each gender category.

The increase in the odds ratios of men in the restructuring period as compared to the ISI stage shows that, despite the reduction in opportunities for rising socially into stratum I, there has been a reduction in relative inequality by stratum of origin in the male distribution, except for those from agricultural backgrounds. The opposite is true of women: those from strata I and II are in a very different situation from the rest.

Lastly, table 12 analyses the evolution of gender inequality, i.e., the male odds ratios for advancement to stratum I compared to the odds for women. ${ }^{14}$

A value higher than 1 indicates that men have the advantage over women. The table shows that over the period analysed there is a clear tendency for the male advantage to disappear in the two upper strata. In the ISI years the odds of upper stratum men were almost 13 times as high as those of women in the same class, but they tended to equal out during the transition and shifted modestly but perceptibly in favour of women when the new economic model began to operate. A similar, albeit less drastic movement is seen in the stratum of technical and white-collar workers, since during the transition men still had the advantage over women.

$$
{ }_{14} R_{i 1 m}=\frac{M_{i 1 m}}{M_{i 1 w}}=\frac{\frac{P_{i 1 m}}{1-P_{i 1 m}}}{\frac{P_{i 1 w}}{1-P_{i 1 w}}} \text {, where } m=\text { men and } w=\text { women. }
$$


TABLE 9

Mexico (six cities): Absolute opportunities for moving into stratum I, by gender, taking the restructuring period as the base

\begin{tabular}{|c|c|c|c|c|c|}
\hline \multicolumn{3}{|c|}{ Social stratum of predecessor } & \multirow{2}{*}{$\begin{array}{c}\text { ISI } \\
4.642\end{array}$} & \multirow{2}{*}{$\begin{array}{c}\text { Transition } \\
3.231\end{array}$} & \multirow{2}{*}{$\begin{array}{c}\text { Restructuring } \\
1.000\end{array}$} \\
\hline Men & I & Professionals, managers and executives, employers of more than 5 workers & & & \\
\hline & II & Technical and white-collar workers & 3.033 & 3.052 & 1.000 \\
\hline & III & Small employers and non-professional own-account workers & 1.203 & 0.518 & 1.000 \\
\hline & IV & Skilled workers in industry and formal workers in services & 2.015 & 2.110 & 1.000 \\
\hline & $\mathrm{V}$ & Unskilled workers in industry and informal workers in services & 3.092 & 3.071 & 1.000 \\
\hline & VI & Others (agriculture) & Indeterminate & Indeterminate & 1.000 \\
\hline \multirow[t]{6}{*}{ Women } & I & Professionals, managers and executives, employers of more than 5 workers & 0.254 & 2.148 & 1.000 \\
\hline & II & Technical and white-collar workers & 0.303 & 0.979 & 1.000 \\
\hline & III & Small employers and non-professional own-account workers & 1.559 & 2.533 & 1.000 \\
\hline & IV & Skilled workers in industry and formal workers in services & 5.287 & 4.216 & 1.000 \\
\hline & $\mathrm{V}$ & Unskilled workers in industry and informal workers in services & Indeterminate & Indeterminate & 1.000 \\
\hline & VI & Ejidatarias, small rural landowners and labourers & 0.978 & 1.181 & 1.000 \\
\hline
\end{tabular}

Source: Prepared by the authors using data from CIESAS/INEGI (1996).

TABLE 10

Mexico (six cities): Normalized entropic index of absolute opportunities for social mobility, by gender

\begin{tabular}{|c|c|c|c|c|c|}
\hline \multicolumn{3}{|c|}{ Social stratum of predecessor } & \multirow{2}{*}{$\begin{array}{c}\text { ISI } \\
0.753\end{array}$} & \multirow{2}{*}{$\begin{array}{c}\text { Transition } \\
0.749\end{array}$} & \multirow{2}{*}{$\begin{array}{c}\text { Restructuring } \\
0.784\end{array}$} \\
\hline Men & I & Professionals, managers and executives, employers of more than 5 workers & & & \\
\hline & II & Technical and white-collar workers & 0.765 & 0.799 & 0.791 \\
\hline & III & Small employers and non-professional own-account workers & 0.916 & 0.858 & 0.848 \\
\hline & IV & Skilled workers in industry and formal workers in services & 0.723 & 0.818 & 0.793 \\
\hline & $\mathrm{V}$ & Unskilled workers in industry and informal workers in services & 0.760 & 0.734 & 0.753 \\
\hline & VI & Ejidatarios, small rural landowners and labourers & 0.741 & 0.829 & 0.792 \\
\hline \multirow[t]{6}{*}{ Women } & I & Professionals, managers and executives, employers of more than 5 workers & 0.414 & 0.396 & 0.491 \\
\hline & II & Technical and white-collar workers & 0.603 & 0.431 & 0.382 \\
\hline & III & Small employers and non-professional own-account workers & 0.849 & 0.764 & 0.698 \\
\hline & IV & Skilled workers in industry and formal workers in services & 0.753 & 0.622 & 0.607 \\
\hline & V & Unskilled workers in industry and informal workers in services & 0.606 & 0.690 & 0.641 \\
\hline & VI & Ejidatarias, small rural landowners and labourers & 0.859 & 0.782 & 0.678 \\
\hline
\end{tabular}

Source: Prepared by the authors using data from CIESAS/INEGI (1996).

TABLE 11

Mexico: Relative opportunities for reaching stratum I, by gender

\begin{tabular}{|c|c|c|c|c|c|}
\hline \multicolumn{3}{|c|}{ Social stratum of predecessor } & \multirow{2}{*}{$\begin{array}{c}\text { ISI } \\
1.000\end{array}$} & \multirow{2}{*}{$\begin{array}{c}\text { Transition } \\
1.000\end{array}$} & \multirow{2}{*}{$\begin{array}{c}\text { Restructuring } \\
1.000\end{array}$} \\
\hline Men & I & Professionals, managers and executives, employers of more than 5 workers & & & \\
\hline & II & Technical and white-collar workers & 0.213 & 0.308 & 0.326 \\
\hline & III & Small employers and non-professional own-account workers & 0.059 & 0.037 & 0.228 \\
\hline & IV & Skilled workers in industry and formal workers in services & 0.043 & 0.065 & 0.100 \\
\hline & V & Unskilled workers in industry and informal workers in services & 0.064 & 0.091 & 0.096 \\
\hline & VI & Ejidatarios, small rural landowners and labourers & 0.039 & 0.049 & 0.000 \\
\hline \multirow[t]{6}{*}{ Women } & $\mathrm{I}$ & Professionals, managers and executives, employers of more than 5 workers & 1.000 & 1.000 & 1.000 \\
\hline & II & Technical and white-collar workers & 0.341 & 0.130 & 0.286 \\
\hline & III & Small employers and non-professional own-account workers & 0.895 & 0.172 & 0.146 \\
\hline & IV & Skilled workers in industry and formal workers in services & 0.383 & 0.036 & 0.018 \\
\hline & V & Unskilled workers in industry and informal workers in services & 0.000 & 0.023 & 0.000 \\
\hline & VI & Ejidatarias, small rural landowners and labourers & 0.215 & 0.031 & 0.056 \\
\hline
\end{tabular}

Source: Prepared by the authors using data from CIESAS/INEGI (1996). 
TABLE 12

Mexico (six cities): Male/female opportunity ratios

\begin{tabular}{llrr}
\hline Social & stratum of predecessor & ISI & Transition \\
\hline I & Professionals, managers and executives, employers of more than 5 workers & 12.822 & 1.057 \\
II & Technical and white-collar workers & 8.006 & 0.702 \\
III & Small employers and non-professional own-account workers & 0.848 & 0.800 \\
IV & Skilled workers in industry and formal workers in services & 1.452 & 1.906 \\
V & Unskilled workers in industry and informal workers in services & Indeterminate & 4.111 \\
VI & Ejidatarios, small rural landowners and labourers & 2.345 & 1.688 \\
\end{tabular}

Source: Prepared by the authors using data from CIESAS/INEGI (1996).

Men whose predecessors were small employers or non-professional own-account workers (stratum III), or skilled workers in industry and formal workers in services (stratum IV), have greater opportunities to attain the top stratum than women in those same occupational categories. There is a difference between these two strata, however, since men from stratum IV systematically improved their advantage over the three periods, having

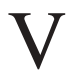

\section{Conclusions}

This paper sets out to study the changes that have occurred: i) in opportunities for occupational attainment; ii) in the inequality of such attainment, and iii) in the interaction between the growing participation of women in employment and changes in occupational opportunities between and within the genders. We hope it will contribute to the debate about structural change in Mexican and Latin American society during the period of stabilizing development, the crisis that followed and the introduction of the model based on freer trade and liberalization of the domestic economy.

The strategy followed was to take the attainments of class or stratum I (professionals, managers and executives and large employers) as a reference point. This was decided upon to avoid reaching erroneous conclusions about occupational attainments by gender (Portocarero, 1989) and to obviate the need to bring in analyses of the restratification process in Mexican society (Rubalcava, 1999). Since the 1960s, and still now, the occupations comprised in class I have stood high above the rest in every sense, for both men and women.

Among the findings, we would stress, firstly, a considerable decline from 1988 onward in the opportunities of all occupational strata for rising to started with a modest advantage during the ISI years, while those from III were at a disadvantage to women during the import substitution years, and even more so during the transition, but drew level with them under the new model. Thus, the male advantage disappeared and a female one was created in strata I and II, and masculine privilege was strengthened in stratum IV, while opportunities for social mobility were evened out in III.

class I or remaining there. That year, in our judgement, marked the boundary between the old import substitution model and the new model. The only exception to this pattern is found among those from class III (small employers and non-professional ownaccount workers), where the decline is much less marked. It should be noted that the market position of members of that class shielded them, at least in part, from the consequences of the policies that reduced wages and incomes in Mexico in the early 1980s.

The decline in opportunities or probabilities of attainment is not directly related to economic growth. While growth in the economy and formal employment has been very low since 1982, attainment probabilities began to fall in 1988. This, in our opinion, indicates that the change in the mobility system is closely related to the accumulation model and not merely to economic growth.

In the second place, this decline has been greater among those from the urban and agricultural working classes than in the remaining strata. The relative decline in attainment opportunities displays three tendencies: diminishing in the first three strata, holding steady in the fourth, and increasing among those from the fifth and sixth strata. This finding is a first indicator of 
growing inequality and, in particular, of a strengthening of the barrier separating the attainments of the higher and intermediate classes from those of workers, lowlevel services workers and farm workers in general.

Thirdly, the analysis of the entropic indices showed that the dispersion of individuals from each class through the occupational structure was constantly declining; i.e., there was greater occupational fluidity in society in the years when the old stabilizing development model applied than in the years during which the new model has applied. This finding, combined with the previous one, allows us to state that, as well as intensifying inequality, the Mexican occupational mobility system has become more rigid. In other words, the occupation of the respondent's father or breadwinner has become a more robust predictor of the respondent's own occupational destination. This indicates that the role of the social institutions that contribute to greater equity in the competition for occupational positions (consumption subsidies for the lower classes, social education, health and urban services) is becoming weaker and weaker within the social mobility system in Mexico.

This is true of people working in urban employment generally in the Mexican cities covered by the data and, we believe, in urban Mexico as a whole. But the inclusion of the gender variable in the analysis allows it to be shown that the results are a composite of difference tendencies for men and women.

While the opportunities for male attainment fall continuously from the first period to the second and from this to the third, for women there is found to be: i) a substantial improvement in opportunities from the first period to the second and ii) a decline that is large, but smaller than for men, from the second to the third. Thus, the apparent stability of opportunities between the first two periods is actually composed of a worsening for men and an improvement for women, while from the second to the third the tendency is similar for both, although it differs in degree. This behaviour must be related to the continuing expansion of educational and occupational opportunities for women since the 1970s. However, the strength of this phenomenon during the transition period (1982-1988), when modern services were no longer growing, also suggests it is possible that employers adopted a strategy in those years of recruiting women to senior positions, possibly because women are paid less and are less wellplaced to negotiate with employers than men. But this is a hypothesis which will have to be explored in another study. The final outcome, in any event, points to reduced inequality in opportunities for attainment by gender. This diminution, however, is not linear from top to bottom of the occupational structure.

The detailed analysis of developments in social mobility opportunities within the gender groups, however, shows that all in all, while opportunities for reaching the top of the stratification have diminished for men in all social classes, for women the situation is more involved. Opportunities for attainment among the female descendants of predecessors situated at the top of the occupational stratification increased during the economic restructuring years in relation to the prospects they had while the old economic model was in place; but among women from the lower classes the opposite movement was seen, i.e., there was a marked decline in their opportunities over the same period. The composition of the two movements meant that inequality between women by class of origin increased. This creates a striking difference between the genders, since men from the higher classes have seen the advantage gap between them and men from the lower strata narrow, reducing inequality by class of origin.

These tendencies are manifested in entropic indices that are higher for men than for women, while over time these indices show a rising trend (less determined by class of origin) for men and a falling one (more determined by class of origin) for women. These patterns suggest the conclusion that the occupational structure tends to be more fluid for men than for women and that this fluidity is increasing in the case of the former and tending to diminish in the case of the latter.

The interplay of these movements has meant that inequality in opportunities for achievement is now greater among women than among men. It may be suggested that this finding is related to the greater rapidity of changes in fertility and family size in the higher classes, and to a greater perception that women have to perform a role as workers for most of their adult life, i.e., that they need to "have a career", so that their parents tend to invest more in their education. But once again, this is a hypothesis that will need to be explored later.

The above analysis supports the idea that, in the years which other analysts have shown to be a time of large, sudden changes, Mexico has undergone a profound transformation affecting not only incomes (Rubalcava, 1999), poverty and inequality (Cortés, 2000), but also the underlying ways in which society distributes opportunities among the population. This analysis ought to be updated at later dates, taking advantage of the availability of databases such as the Retrospective Demographic Survey conducted in the country in 2000 and 2001. 
Notwithstanding the above results, it should be noted that our analysis has certain limitations. One important one, with a number of consequences, is that as the labour market evolves, so may the relationship observed between the outset and the maximum attainment of people's careers. The market has become more rigid, and differences of education could, on the one hand, help many men originally from class I to return to that class, even if their first job was in a different one. For the same reason, it may become less likely that people from low classes will succeed in reaching stratum I with time. In other words, the analysis could mask a growing inequality among men. Similarly, our analysis finds that equality in occupational opportunities by gender has increased. But hitherto men's careers have shown more of an upward tendency than women's. We will not know for some time whether men will maintain this advantage over women or whether, conversely, their careers will become more alike, which would reinforce the equalizing tendency found in this study. Third, it is clear that, up to the time when this analysis was carried out, the occupations represented in class I have been "winning" ones, i.e., have virtually guaranteed a position at the top of the income (decile I) and occupational structure. But increasing education in the population at large, and the downgrading of many professions, could make it necessary to draw finer distinctions within class I to separate those who are really attaining success by entering that stratum and those (middle-ranking managers and executives, for example) who are losing a considerable part of their income and status. Lastly, class or stratum I in our distribution does not include large employers, and class or stratum VI does not properly represent rural labourers, owing to the limitations of the occupational and household surveys conducted in cities (Cortés, 2002). This means that developments in the inequality of opportunity cannot be calculated for this stratum. In any event, though, we hope that the foregoing results will spur on new research projects to answer these new questions.

APPENDIX

Mexico (six cities): Results matrix

Intergenerational mobility: First occupation, by predecessor's occupation, period and gender ${ }^{\mathrm{a}-\mathrm{b}-\mathrm{c}}$

\begin{tabular}{|c|c|c|c|c|c|c|c|c|c|c|}
\hline \multirow{2}{*}{$\begin{array}{l}\text { Period of } \\
\text { occupations }\end{array}$} & \multirow[t]{2}{*}{ Gender } & & & \multicolumn{6}{|c|}{ First job: those in work only } & \multirow[t]{2}{*}{ Total } \\
\hline & & & & $\bar{I}$ & II & III & IV & $\mathrm{V}$ & $\mathrm{VI}$ & \\
\hline \multirow{14}{*}{$\begin{array}{r}\text { Restructuring } \\
(\text { after 1987)) }\end{array}$} & \multirow[t]{7}{*}{ Male } & Predecessor's & I & 11 & 83 & 9 & 32 & 24 & 6 & 165 \\
\hline & & (breadwinner's) occupation & II & 12 & 210 & 30 & 142 & 116 & 18 & 528 \\
\hline & & & III & 13 & 198 & 67 & 178 & 289 & 65 & 810 \\
\hline & & & IV & 6 & 196 & 63 & 275 & 275 & 32 & 847 \\
\hline & & & $\mathrm{V}$ & 3 & 110 & 27 & 95 & 192 & 13 & 440 \\
\hline & & & VI & & 68 & 3 & 72 & 52 & 81 & 276 \\
\hline & & Total & & 45 & 865 & 199 & 794 & 948 & 215 & 3066 \\
\hline & \multirow[t]{7}{*}{ Female } & Predecessor's & I & 12 & 98 & 6 & 10 & 4 & & 130 \\
\hline & & (breadwinner's) occupation & II & 10 & 294 & 6 & 26 & 16 & 2 & 354 \\
\hline & & & III & 8 & 272 & 17 & 89 & 149 & 12 & 547 \\
\hline & & & IV & 1 & 322 & 12 & 107 & 83 & 10 & 535 \\
\hline & & & V & & 145 & 7 & 54 & 72 & 3 & 281 \\
\hline & & & VI & 1 & 75 & 2 & 10 & 65 & 24 & 177 \\
\hline & & Total & & 32 & 1206 & 50 & 296 & 389 & 51 & 2024 \\
\hline \multirow[t]{14}{*}{ Mixed (1982-1987) } & \multirow[t]{7}{*}{ Male } & Predecessor's & I & 24 & 61 & 15 & 15 & 8 & 5 & 128 \\
\hline & & (breadwinner's) occupation & II & 23 & 166 & 23 & 61 & 64 & 10 & 347 \\
\hline & & & III & 7 & 218 & 67 & 186 & 263 & 95 & 836 \\
\hline & & & IV & 9 & 155 & 48 & 206 & 163 & 26 & 607 \\
\hline & & & $\mathrm{V}$ & 7 & 86 & 12 & 75 & 142 & 17 & 339 \\
\hline & & & VI & 4 & 98 & 19 & 50 & 85 & 101 & 357 \\
\hline & & Total & & 74 & 784 & 184 & 593 & 725 & 254 & 2614 \\
\hline & \multirow[t]{7}{*}{ Female } & Predecessor's & I & 19 & 80 & 1 & 3 & 1 & 2 & 106 \\
\hline & & (breadwinner's) occupation & II & 8 & 232 & 6 & 23 & 17 & 3 & 289 \\
\hline & & & III & 20 & 281 & 46 & 83 & 108 & 14 & 552 \\
\hline & & & IV & 3 & 213 & 12 & 65 & 90 & & 383 \\
\hline & & & $\mathrm{V}$ & 1 & 79 & 8 & 31 & 73 & 4 & 196 \\
\hline & & & VI & 1 & 62 & 9 & 14 & 40 & 24 & 150 \\
\hline & & Total & & 52 & 947 & 82 & 219 & 329 & 47 & 1676 \\
\hline
\end{tabular}


(continued)

\begin{tabular}{|c|c|c|c|c|c|c|c|c|c|c|}
\hline \multirow{2}{*}{$\begin{array}{l}\text { Period of } \\
\text { occupations }\end{array}$} & \multirow[t]{2}{*}{ Gender } & & & \multicolumn{6}{|c|}{ First job: those in work only } & \multirow[t]{2}{*}{ Total } \\
\hline & & & & $\mathrm{I}$ & II & III & IV & $\mathrm{V}$ & $\mathrm{VI}$ & \\
\hline \multirow[t]{14}{*}{ ISI (until 1982) } & \multirow[t]{7}{*}{ Male } & Predecessor's & I & 64 & 101 & 9 & 39 & 26 & 18 & 257 \\
\hline & & (breadwinner's) occupation & II & 34 & 273 & 17 & 82 & 82 & 28 & 516 \\
\hline & & & III & 31 & 361 & 202 & 238 & 382 & 397 & 1611 \\
\hline & & & IV & 11 & 157 & 53 & 254 & 241 & 60 & 776 \\
\hline & & & $\mathrm{V}$ & 9 & 66 & 35 & 80 & 207 & 36 & 433 \\
\hline & & & VI & 12 & 129 & 42 & 119 & 164 & 467 & 933 \\
\hline & & Total & & 161 & 1087 & 358 & 812 & 1102 & 1006 & 4526 \\
\hline & \multirow[t]{7}{*}{ Female } & Predecessor's & $\mathrm{I}$ & 3 & 96 & 4 & 9 & 7 & & 119 \\
\hline & & (breadwinner's) occupation & II & 2 & 150 & 23 & 31 & 21 & 2 & 229 \\
\hline & & & III & 19 & 310 & 104 & 148 & 215 & 44 & 840 \\
\hline & & & IV & 4 & 150 & 45 & 96 & 109 & 4 & 408 \\
\hline & & & $\mathrm{V}$ & & 69 & 19 & 27 & 172 & 2 & 289 \\
\hline & & & VI & 2 & 100 & 39 & 67 & 104 & 50 & 362 \\
\hline & & Total & & 30 & 875 & 234 & 378 & 628 & 102 & 2247 \\
\hline
\end{tabular}

a Occupational strata:

I: Professionals, managers and executives and employers of more than five workers.

II: Technical and white-collar workers.

III: Small employers and non-professional own-account workers.

IV: Skilled workers in industry and formal workers in services.

$\mathrm{V}$ : Unskilled workers in industry and informal workers in services.

VI: Ejidatarios, small rural landowners and labourers.

b The figures in this table are unweighted. Expansion factors are available.

c The total sample is 9/13 of the sample of the National Urban Employment Survey for these cities.

\section{Bibliography}

Balán, J., H. Browning and E. Jelin (1973): Men in a Developing Society: Geographic and Social Mobility in Monterrey, Mexico, Austin, University of Texas Press.

Boltvinik, J. and E. Hernández Laos (1999): Pobreza y distribución del ingreso en México, Mexico City, Siglo Veintiuno Editores.

Breiger, R.L. (ed.) (1990): Social Mobility and Social Structure, Cambridge, Cambridge University Press.

Cerrutti, M. (2000a): Economic reform, structural adjustment and female participation in the labor force in Buenos Aires, Argentina, World Development, vol. 28, No. 5, May, Amsterdam, Elsevier.

(2000b): Intermittent employment among married women: a comparative study of Buenos Aires and Mexico City, Journal of Comparative Family Studies, vol. 31, No. 1, Paris, Committee for International Cooperation in National Research in Demography (CICRED).

CIESAS/INEGI (Centre for Research and Higher Learning in Social Anthropology/National Institute of Statistics, Geography and Information) (1996): Género, edad, familia y trabajo: encuesta sobre movilidad social y organización doméstica en seis ciudades mexicanas, Mexico City, electronic file.

CONAPO (National Population Council) (1999): Envejecimiento demográfico en México: retos y perspectivas, Mexico City. (2000): La situación demográfica de México, Mexico City.

Contreras, E. (1978): Estratificación y movilidad social en la ciudad de México, Mexico City, National Autonomous University of Mexico (UNAM).

Cortés, F. (2000): La distribución del ingreso en México en épocas de estabilización y reforma económica, Mexico City, Centre for Research and Higher Learning in Social Anthropology (CIESAS)/Miguel Ángel Porrúa.
(2002): El cálculo de la pobreza en México a partir de la encuesta de ingresos y gastos, Comercio exterior, vol. 51, No. 10, Mexico City, Banco Nacional de Comercio Exterior (BANCOMEXT), October.

Cortés, F. and R.M. Rubalcava (1991): Autoexplotación forzada y equidad por empobrecimiento, Mexico City, El Colegio de México.

De Barbieri, T. (1989): La mujer, Demos 2: Carta demográfica sobre México, Mexico City.

De Oliveira, O. (1988): El empleo femenino en tiempos de recesión económica: tendencias recientes, paper presented at the Coloquio sobre fuerza de trabajo femenina urbana, Mexico City, National Autonomous University of Mexico (UNAM).

Erikson, R. and J. Goldthorpe (1992): The Constant Flux: A Study of Class Mobility in Industrial Society, Oxford, Clarendon Press.

Escobar Latapí, A. (1996): Crisis, Restructuring and State Action in Mexico, paper presented at the Seminar on Restructuring and Globalization in Latin America, Austin, Institute of Latin American Studies, University of Texas.

(2000a): Employment Trends in Mexico: Reversing a 15 Year Loss?, document prepared for the Grupo ITAM-Carnegie de estudios sobre relaciones México-Estados Unidos.

(2000b): PROGRESA y cambio social en el campo en México, in E. Valencia, A.M. Tepichín and M. Gendreau (eds.), Los dilemas de la política social: ¿cómo combatir la pobreza?, Guadalajara, University of Guadalajara/Ibero-American University/Instituto Tecnológico y de Estudios Superiores de Occidente (ITESO).

(2000c): PROGRESA y el bienestar de las familias: los hallazgos, Evaluación de resultados del PROGRESA: impacto a nivel comunitario, Mexico City, PROGRESA. 
Escobar, A. and M. González de la Rocha (1995): Crisis, restructuring and urban poverty in Mexico, Environment and Urbanization, vol. 7, No. 1, London, International Institute for Environment and Development (IIMAD).

Featherman, D., F. Lancaster Jones and R. Hauser (1975): Assumptions of social mobility research in the U.S.: the case of occupational status, Social Science Research, vol. 4, New York, Social Science Research Council.

García, B. and O. de Oliveira (1994): Trabajo femenino y vida familiar en México, Mexico City, El Colegio de México.

(forthcoming): Heterogeneidad laboral y calidad de los empleos en las principales áreas urbanas de México, Revista latinoamericana de estudios del trabajo, Geneva, International Labour Organization (ILO).

Goldthorpe, J. (1987): Social Mobility and Class Structure in Modern Britain, Oxford, Clarendon Press.

González de la Rocha, M. (1988): Economic crisis, domestic reorganization and women's work in Guadalajara, San Diego, University of California/CIESAS Occidente.

(1991): Economic crisis, domestic reorganization and women's work in Guadalajara, in M. González de la Rocha and A. Escobar (eds.), Social Responses to Mexico's Economic Crisis, La Joya, University of California.

(1994): The Resources of Poverty: Women and Survival in a Mexican City, London, Blackwell.

González de la Rocha, M. and A. Escobar Latapí (1986): Crisis y adaptación social: hogares de Guadalajara, paper presented at the Third Meeting of the Mexican Demography Society, Mexico City, El Colegio de México, November.

Haller, M. (1990): Class Structure in Europe: New Findings from East-West Comparisons of Social Structure and Mobility, Armonk, N.Y., M.E. Sharpe.

Hernández Laos, E. (2001): Globalización, distribución del ingreso y pobreza en México, unpublished.

Hernández Licona, G. (1997): Oferta laboral familiar y desempleo en México: los efectos de la pobreza, El trimestre económico, vol. 64, No. 4, Mexico City, Fondo de Cultura Económica (FCE), October/December.

INEGI (National Institute of Statistics, Geography and Information) (2002): Banco de Información Económica (BIE), http://dgcnesyp.inegi.gob.mx.

Lipset, S.M. and H.L. Zetterberg (1959): Social mobility in industrial societies, in S.M. Lipset and R. Bendix (eds.), Social Mobility in Industrial Societies, Berkeley, University of California Press.
Muñoz, H., O. de Oliveira and C. Stern (eds.) (1977): Migración y desigualdad social en la Ciudad de México, Mexico City, National Autonomous University of Mexico (UNAM).

Pacheco, E. and S. Parker (1996): Participación económicamente activa femenina en el México urbano: un breve recuento y algunos hallazgos recientes, Problemas del desarrollo, vol. 27, No. 106, National Autonomous University of Mexico (UNAM), July/September.

Parker, S. (1999): Niveles salariales de hombres y mujeres: diferencias por ocupación en las áreas urbanas de México, in B. Figueroa Campos (ed.), México diverso y desigual: enfoques sociodemográficos, Mexico City, El Colegio de México/Mexican Demography Society (SOMEDE).

Payne, G. and P. Abbott (1990): The Social Mobility of Women: Beyond Male Mobility Models, London, The Falmer Press.

Portocarero, L. (1989): Trends in occupational mobility: the gender gap in Sweden, Acta sociológica, vol. 32, No. 4, London, Sage Publications.

Reyes Heroles, J. (1983): Política macroeconómica y bienestar en México, Mexico City, Fondo de Cultura Económica.

Rubalcava, R.M. (1999): Necesidades, recursos y posibilidades: el ingreso de los hogares mexicanos en el período 1984-1994. Guadalajara, Centre for Research and Higher Learning in Social Anthropology (CIESAS).

Selby, H., A.D. Murphy and S.A. Lorenzen (1990): The Mexican Urban Household: Organizing for Self-Defense, Texas, University of Texas Press.

Sorokin, P.A. (1927): Social Mobility, Glencoe, United States, Free Press.

Solís, P. (2002): Structural Change and Men's Work Lives: Transformations in Social Stratification and Occupational Mobility in Monterrey, Mexico, thesis, Austin, University of Texas.

Theil, H. (1972): Statistical Decomposition Analysis, Amsterdam, North Holland Press.

Tuirán, R. (1993): Las respuestas de los hogares de sectores populares urbanos frente a la crisis: el caso de la Ciudad de México, in B. Navarro Raúl and H. Hernández Bringas (coords.), De población y desigualdad social en México, Mexico City, Regional Informatics Centre on Women (CRIM)/ National Autonomous University of Mexico (UNAM).

(coord.) (2000): Migración México-Estados Unidos: presente y futuro, Mexico City.

UNRISD (United Nations Research Institute for Social Development) (2000): La mano visible: asumir la responsabilidad por el desarrollo social, Geneva.

World Bank (2000): Attacking Poverty, Washington, D.C. 